\title{
Intestinal nematodes and pulmonary tuberculosis
}

\author{
Nematóides intestinais e tuberculose pulmonar \\ Ricardo Tristão-Sá', Rodrigo Ribeiro-Rodrigues', Luciléia T. Johnson', \\ Fausto Edmundo L. Pereira ${ }^{1}$ and Reynaldo Dietze ${ }^{1}$
}

\begin{abstract}
We report a significantly higher prevalence of intestinal nematodes in patients with pulmonary tuberculosis (TB) compared to a matched control group: $33 / 57$ (57.8\%) in patients with TB and 18/86 (20.9\%) in the control group; $O R=5.19 ; 95 \% \mathrm{Cl}=2.33-11.69 ; p=0.000)$. When TB patients eosinophilia was also significantly higher among those with intestinal parasites (69.8\%) compared to those without this condition (45.6\%). We hypothesized that the immune modulation induced by nematodes is a factor that enhances TB infection/ progression and that eosinophilia seen in TB patients is a consequence of helminth infection.
\end{abstract}

Key-words: Tuberculosis. Helminthiasis. Strongyloidiasis. Mycobacterium tuberculosis.

Resumo Nesta comunicação relatamos uma prevalência significativamente maior de nematóides intestinais em pacientes com tuberculose pulmonar (TB), comparada a um grupo controle pareado: 33/57 (57,8\%) nos pacientes com TB e 18/86 (20,9\%) no grupo controle; OR=5.19; IC a 95\%=2.33-11.69; $p=0.000)$. Dentre os pacientes com TB, a eosinofilia foi significativamente maior nos pacientes com nematóides intestinais (69,8\%) comparados àqueles sem parasitas (45,6\%). Nossa hipótese é que a imunomodulação induzida por nematóides é fator facilitador da infecção/progressão da doença na TB e que a eosinofilia frequentemente vista em pacientes com TB é secundária à infecção helmíntica.

Palavras-chaves: Tuberculose. Helmintíases. Estrongiloidíase. Mycobacterium tuberculosis.

Immune modulation induced by worm infections can affect the outcome of other infectious diseases ${ }^{2}$. Based on findings from studies related to immunological status of humans with intestinal worms ${ }^{310}$, Bentwich et $\mathrm{al}^{2}$ hypothesized that the eradication of these worms could change the impact of some infectious disease, such as AIDS and tuberculosis. In agreement with this idea it has been reported that either the acute phase of Schistosoma mansoni infection or infections with intestinal nematodes or Toxocara are risk factors for pyogenic liver abscess, pyomyositis and other staphylococcal infections in children and adults 11131415161718 . However, despite evidence supporting the role of helminth infection in the enhancement of other infectious diseases, these arguments are not conclusive ${ }^{5}$.

To verify if there is a higher prevalence of helminth infection in patients with tuberculosis we studied the frequency of intestinal nematodes in patients with and without pulmonary tuberculosis diagnosed at the Hospital Universitário Cassiano Antônio de Morais (HUCAM), Vitória, ES, Brazil.

Data on stool examinations and eosinophil counts were retrieved from the records of 57 patients with pulmonary tuberculosis admitted to HUCAM between September 1997 and August 1999. For control we used a randomized sample of 86 stool examinations from hospitalized adult patients, with other diseases, performed in the routine laboratory of the same Hospital, during the same period. The control group was matched by age, gender and neighborhood. All stool examinations were performed in three samples by the Lutz-Hoffman method.

The most prevalent intestinal nematodes found among the adult in-patient control population were Ascaris lumbricoides, Strongyloides stercoralis,

1. Núcleo de Doenças Infecciosas do Centro Biomédico da Universidade Federal do Espírito Santo, Vitória, ES, Brazil.

Address to: Dr. Reynaldo Dietze. Núcleo de Doenças Infecciosas/CBM/UFES, Av. Marechal Campos 1468, Maruipe, 29040-091 Vitória, ES, Brazil. Fax: 5527 335-7204.

e-mail:rdietze@ndi.ufes.br

Recebido para publicação em 10/1/2002. 
Trichuris trichiura, Ancylostomidae (Necator americanus or Ancylostoma duodenale), respectively. When considered separately, $S$. stercoralis was more prevalent than other nematode species among patients with pulmonary tuberculosis. Schistosoma mansoni occurred in two patients with pulmonary tuberculosis and in two controls.

The frequency of infections by at least one nematode was significantly higher in patients with pulmonary tuberculosis than among the control group. This difference persists if we considered the frequency of Strongyloides stercoralis or the frequency of the other intestinal nematodes grouped together as other nematodes (Table 1).
Eosinophil counts higher than 600 cells $/ \mathrm{mm}^{3}$ were found in 26 out of 57 (45.6\%) patients with tuberculosis and $69.8 \%$ of those who presented one or more intestinal parasites (Table 2).

Our results showed higher prevalence of nematode infection (especially $S$. stercoralis ) in patients with tuberculosis than in controls. Although the two samples, cases and controls, were matched by age, gender and neighborhood, we canot rule out several confounders that are frequent when using in-patients samples. Thus all the conclusions may consider the caveats resulting from the assumption that the two samples are comparable.

Table 1 - Frequency of intestinal nematodes in patients with pulmonary tuberculosis and in patients with diseases other than tuberculosis, admitted at the same hospital.

\begin{tabular}{lccc}
\hline Intestinal worms & $\begin{array}{c}\text { Patients with tuberculosis } \\
\text { positive/total (\%) }\end{array}$ & $\begin{array}{c}\text { Patients without tuberculosis } \\
\text { positive/total (\%) }\end{array}$ & OR (95\% Cl) \\
\hline At least one worm & $33 / 57(57.8)$ & $18 / 86(20.9)$ & $5.19(2.33-11.69)$ \\
Strongyloides stercoralis & $14 / 57(24.5)$ & $7 / 86(8.1)$ & $4.00(1.38-11.80)$ \\
Other nematodes $^{* *}$ & $19 / 57(33.3)$ & $11 / 86(12.3)$ & $3.41(1.37-8.61)$ \\
\hline
\end{tabular}

${ }^{*} \chi^{2}$ test. Nematodes other than S. stercoralis.

Table 2 - Eosinophil counts in patients with pulmonary tuberculosis associated or not with intestinal nematode infection.

\begin{tabular}{lcc}
\hline Group & Eosinophils $/ \mathrm{mm}^{3}$ Mean \pm SD (Median) & Patients with more than 600 eosinophils $/ \mathrm{mm}^{3}$ \\
\hline All patients $(\mathrm{N}=57)$ & $585.3 \pm 548.8(503)$ & $28 / 57(49.1 \%)$ \\
Without intestinal worms $(\mathrm{N}=34)$ & $437.2 \pm 545.6(237)$ & $8 / 34(23.5 \%)$ \\
With intestinal worms $(\mathrm{N}=23)$ & $804.3 \pm 485.8(686)$ & $19 / 23(82.6 \%)^{*}$ \\
\hline
\end{tabular}

${ }^{*} \mathrm{p}=0.000 ; \chi^{2}$ test

The high frequency of intestinal nematodes in patients with pulmonary tuberculosis suggests that the immune modulation induced by worms may facilitate the infection with Mycobacterium tuberculosis and disease progression. This suggestion corroborates previous reports showing that lymphocyte activation, defects on signal transduction, and anergy can be associated with intestinal helminth infection in humans ${ }^{3410}$. Furthermore, our results support a recent observation showing that the frequency of intestinal nematodes was significantly higher among patients with multibacillary forms of leprosy when compared with patients with paucibacillary leprosy or controls without leprosy ${ }^{7}$. Also our results corroborate with the observation that the response to PPD, in vivo and in vitro, was diminished in children with intestinal parasites and improved after deworming ${ }^{8}$.
Eosinophilia has not been reported in patients with tuberculosis ${ }^{9}$ but high levels of IgE during pulmonary tuberculosis were recently reported, in South Africa where intestinal worms are endemic ${ }^{1}$. Both eosinophilia and high levels of IgE are consequences of Th2 activation, a preferential response induced by intestinal worms ${ }^{6}{ }^{12}$. Thus, the results presented here indicate that a possible cause of eosinophilia (and possibly of the high levels of $\lg \mathrm{E}$ ) in patients with pulmonary tuberculosis could be intestinal helminth infections.

A case control study and the study of immune response in patients with pulmonary tuberculosis associated or not to helminth infection are in progress in our laboratory in an attempt to clarify the relationship between the two infections.

\section{REFERENCES}

1. Adams JFA, Scholvinck EH, Gie RP, Potter PC, Beyers N, Beyers AD. Decline in total IgE after treatment for tuberculosis. The Lancet 353: 2030-2033, 1999.

2. Bentwich Z, Kalinkovich A, Weisman Z, Borkov G, Beyers N. Can eradication of helminthic infections change the face of AIDS and tuberculosis? Immunology Today 20: 485-487, 1999.

3. Bentwich Z, Weisman Z, Moroz C, Bar-Yehuda S, Kalinkovich A. Immune disregulation in Ethiopian immigrants in Israel: relevance to helminth infections? Clinical and Experimental Immunology 103: $239-243,1996$
4. Borkow G, Leng Q, Weisman Z, Stein M, Galai N, Kalinkovich A, Bentwich Z. Chronic immune activation associated with intestinal helminth infections results in impaired signal transduction and anergy. Journal of Clinical Investigation 106:1053-1060, 2000.

5. Bundy D, Sher A, Michael E. Good Worms or Bad Worms? Do worm Infections Affect the Epidemiological Patterns of Other Diseases? Parasitology Today 16:273-274, 2000.

6. Cooper PJ, Chico ME, Sandoval C, Espinel I, Guevara A, Kennedy MW, Urban Jr JF, Griffin GE, Nutman TB. Human Infection with Ascaris lumbricoides is associated with a polarized 
cytokine response. Journal of Infectious Diseases 182:12071213, 2000.

7. Diniz LM, Zandonaide E, Dietze R, Pereira FEL, RibeiroRodrigues R. Do intestinal nematodes increase the risk for multibacillary leprosy? The American Journal of Tropical Medicine and Hygiene 65: 852-854, 2001.

8. Elias D, Wolday D, Akuffo H, Petros B, Bronner U, Britton S. Effect of deworming on human $T$ cell responses to mycobacteria antigens in helminth-exposed individuals before and after Bacille Calmette-Guerin (BCG) vaccination. Clinical and Experimental Immunology 123: 219-225, 2001.

9. Goldenberg AS. Hematologic abnormalities and Mycobacterium infections. In: Rom WN, Garay SM (eds) Tuberculosis, Little Brown \& Company, New York, p. 645-655,1996.

10. Kalinkovich A, Weisman Z, Greenberg Z, Nahmias J, Eitan S, Stein M, Bentwich Z. Decreased CD4 and increased CD8 counts with $T$ cell activation is associated with chronic helminth infection. Clinical and Experimental Immunology 114: 414-421,1998.

11. Lambertucci JR, Teixeira R, Navarro MMM, Coelho PZ, Ferreira MD. Liver abscess and schistosomiasis. A new association. Revista da Sociedade Brasileira de Medicina Tropical 23: 239240,1990 .

12. Mahanty S, King C, Kumaraswami V, Regunathan J, Maya A, Jaejaraman K, Abrams JS, Ottersen FA, Nutman TB. IL-4 and II5 -secreting lymphocyte populations are preferentially stimulated by parasite derived antigens in human tissue invasive nematode infections. Journal of Immunology 151: 3704-3711,1993.

13. Moreira-Silva SF, Leite ALA, Ferraz E, Pereira FEL. Nematode infections are risk factors for staphylococcal infection in children. Memórias do Instituto Oswaldo Cruz 97, 2002.

14. Moreira-Silva SF, Pereira FEL. Intestinal nematodes, Toxocara infection and pyogenic liver abscess in children: a possible association. Journal of Tropical Pediatrics 46:167-172, 2000.

15. Pereira FEL, Musso C, Castelo JS. Pathology of pyogenic liver abscess in children. Pediatric and Developmental Pathology 2: 537-543,1999.

16. Rayes AA, Nobre V, Teixeira DM, Serufo JC, Brasileiro-Filho G, Antunes CM, Lambertucci JR. Tropical pyomiositis and human toxocariasis: a clinical and experimental study. American Journal of Medicine 100: 422-425, 2000.

17. Rayes AA, Teixeira DM, Serufo JC, Nobre V, Antunes CM, Lambertucci JR. Human toxocariasis and pyogenic liver abscess: a possible association. American Journal of Gastroenterology 96:563-566, 2001.

18. Teixeira R, Ferreira MD, Coelho PMZ, Brasileiro-Filho G, AzevedoJunior GM, Lambertucci JR. Pyogenic liver abscess and acute schistosomiasis mansoni: report of 3 cases and experimental study. Transactions of the Royal Society of Tropical Medicine and Hygiene 90: 280-283, 1996. 